\title{
Political Connection, Institutional Ownership and Tax Aggressiveness in Indonesia
}

\author{
Yety Anggraini and Wahyu Widarjo
}

\begin{abstract}
This study aims to analyze the effect of political connection and institutional ownership toward tax aggressiveness on manufacturing companies listed on Indonesia Stock Exchange. Samples for this study are 62 manufacturing companies listed between the periods of 2014 - 2018, hence obtained 310 observations. Result of this study shows that political connection of the directors and institutional ownership have positive and significant effect toward tax aggressiveness, while the political connection of the board of commissioners does not significantly affect toward the tax aggressiveness. Furthermore, this study also finds the difference of political connection and institutional ownership between big companies and small companies. The effect of political connection of the directors is stronger in small companies than big companies, while the effect of political connection of the board of commissioners toward tax aggressiveness is stronger in big companies than small companies.
\end{abstract}

Index Terms - political connection, institutional ownership, tax aggressiveness.

\section{INTRODUCTION}

Tax is one of the biggest national income. This is the case for most of the countries in the world, including Indonesia. Data from the ministry of finance in the last ten years shows there is a gap between the target income from taxation and its realization [14]. This indicates tax noncompliance in Indonesia. Tax noncompliance is proved by some news in mass media about the practice of tax avoidance and tax evasion committed by some companies. For instance, the case of tax evasion by PT. Asian Agri in which the manager was sentenced to prison and a fine of 2.5 trillion rupiah. Another phenomenal case is Panama Papers that appeared in both national and international news. Some names mentioned in the case of Panama Papers include Indonesian big businessmen [8].

Some literatures show there are various factors that affect tax aggressiveness, such as executive compensation [2], leverage [17], and political connection [20]. One of important factors that can be studied further in Indonesia is political connection. It is because Indonesia is one of biggest democratic nations in the world, so that politics becomes integral part of people's way of living. Hence, everything related to politics will be observed by media and government, including the political connection issue of public corporations in Indonesia. Companies with political connection are considered to have an advantage in terms of easy access to information related to changes in tax regulations [21] and ease of gaining access to win tenders for profitable government contracts [10].
Studies of relation between political connection and tax aggressiveness have been done previously by some researchers. However, they have inconsistent results. Some studies by reference [1], [4], [16], [27], [7], and [13] show positive effect of political connection toward tax aggressiveness, but studies by [30] and [24] show negative effect of political connection toward tax aggressiveness. This inconsistency might be caused by some factors such as the difference between national regulations, different variables of tax aggressiveness measured in the studies, different types of industries analyzed in the studies, as well as the period in which the studies took place.

This study is different from the previous studies in some aspects. First, this study adds institutional ownership into the variables measured as a factor that affects tax aggressiveness. The addition of institutional ownership into the variables measured is because the institution owner has a very important role in maintaining the harmony between the interest of management and interest of the shareholders. The presence of institution owner can help to monitor the corporate management in taking action to strengthen the better mechanism for corporate governance [25]. Therefore, institutional ownership is expected to reduce the practice of tax aggressiveness. Second, this study specifically analyzes manufacturing companies listed in Indonesia Stock Exchange. Manufacturing companies are chosen as the study object with some consideration: 1) manufacturing companies are the biggest in number of industrial sectors in Indonesia Stock Exchange, that makes the tax contribution from manufacturing companies is relatively bigger than other industrial sectors, 2) manufacturing companies have higher business complexity than other industrial sectors. Hence, the probability of committing the related party transaction or transfer pricing in order to minimize the tax liabilities is bigger than other industrial sectors, 3) the last difference of this study is this study analyzes the comparison between the effect of political connection and institutional ownership toward tax aggressiveness in big companies and small companies as well as analyzes the book tax differences as an additional variable for tax aggressiveness.

The next part of this article is to explain the theoretical basis and the hypothesis development, and then the methodology and result of the study. The last part of this article is conclusion, limitation, and suggestion for further study. 


\section{THEORETICAL BASIS AND HYPOTHESIS DEVELOPMENT}

\section{A. Political Connection of Directors and Tax Aggressiveness}

According to reference [19] political connection indirectly is believed to be a valuable resource for most of companies in achieving their goals. Generally, companies with political connection usually are more often to commit tax aggressiveness. This is because the companies have more "protection" from government, hence lower risk for the practice of tax aggression to be detected.

According to Indonesian Constitution No. 47 year 2007 regarding limited company, Indonesia is a nation that applies two tier board system, dividing authority of management into two levels: management and company supervision. Director is fully responsible for the management as well as running the company to accomplish the goal. Profit earned by the company is one of indicators of the director's performance. The bigger the profit, the bigger the bonus and the remuneration the director earns. However, increased profit means increasing the tax expense that the company must pay. This causes conflict of interest between the director and the company owner in the context of taxation. Studies by reference [16] and [26] show the positive effect of director's political connection toward tax aggressiveness. Furthermore, research [30] explains that there are two sides in the relation between political connection and tax aggressiveness, which are political favoritism effect and bureaucratic incentive effect. This study assesses that the perspective we need to use in order to precisely view the relation between director's political connection and tax aggressiveness is the political favoritism effect. This means the stronger the director's political connection, the higher the tax aggressiveness. Therefore, the first hypothesis in this study is as follows:

$H_{1}$ : Director's political connection affects positively toward Tax Aggressiveness.

\section{B. Political Connection of the Board of Commissioners and Tax Aggressiveness}

Board of Commissioners functions as the supervisor in the company as well as to give suggestion regarding the policies made by the directors in the framework of company management. Board of Commissioners is the representatives of the company owners. Generally, the owners want the low tax payments. However, if the practice of tax management is committed aggressively and leads to an attempt of tax evasion violating regulation, it will harm the company. It may cost the equity value for the shareholders or the company owners. Nevertheless, tax aggressiveness can also affect the reputation and survival of the company in the future. Hence, in the context of taxation, to assess precisely the relation between political connection of the board of commissioners and the tax aggressiveness we use the perspective of bureaucratic incentive effect.

Some previous studies have shown that the political connection of the board of commissioners has negative effect toward tax aggressiveness (see [24], [30], and [13]). Board of commissioners is thought to be more conservative and longterm oriented in making decisions regarding company taxation. Therefore, company tends to adhere and obey the tax regulations. This corresponds to the bureaucratic incentive effect hypothesis. Based on the theoretical review and results of those studies, hence the second hypothesis in this study is as follows:

\section{$\mathrm{H}_{2}$ : Political connection of the board of commissioners affects negatively toward tax aggressiveness}

\section{Institutional Ownership and Tax Aggressiveness}

Institutional ownership is defined as the stock proportion of a company owned by an institution. Institution referred here is such as mutual fund companies, investment companies, pension fund companies, insurance companies, and private foundations or other big business entities that manage an amount of fund on behalf of other people. Institutional ownership within a company itself will affect the company's management because there will be firm monitoring and disciplinary supervision toward any opportunistic attitude in the management that will affect information efficiency resulted from information transparency to the stock market [5], [28]. Stock ownership by this institution represents voting power or rights from the institutional owners that can be used to support the implementation of good governance in order to improve work ethics and company performance.

A study by reference [22] shows that institutional ownership affects negatively toward tax aggressiveness. The same result is also shown in the study by [27] and [29]. On the contrary, reference [15] shows that the more institutional ownership in US companies will cause higher concentration of ownership that will end up in tax aggressiveness. However, that result also shows that the level of tax aggressiveness occurs in short-term investment by the institutions, while in the long-term investment by the institutions relatively will not drive the practice of tax aggressiveness. According to those results, hence the third hypothesis in this study is formulated as follows:

H3: Institutional ownership affects negatively toward Tax Aggressiveness.

\section{RESEARCH MethodOLOGY}

\section{A. Population and Samples}

This study uses secondary data obtained from financial statements from the manufacturing companies listed in Indonesia Stock Exchange 2014-2018. The total number of population within 5 years is 780 observations. Samples were taken using the purposive sampling method. Inclusive criteria used in this study are manufacturing companies that were not delisted within the observation period and had positive values of profit in their bookkeeping. Companies with negative values of profit in their bookkeeping are eliminated because it may cause distortion in ETR [6], [18]. According to the criteria, only 62 companies that can be analyzed as samples in this study, hence there are 310 observations.

\section{B. Operational Definition and Variable Measurement}

Tax aggressiveness (dependent variable) is measured using ETR (Effective Tax Rate). The use of ETR is based on some consideration. Firstly, ETR is one of tax aggressiveness parameters most often used in the study of tax aggressiveness (see [1], [9], [18], [16], [24], [27], [7], 
and [3]). Secondly, the approach of tax aggressiveness measurement using ETR can give the overall portrayal regarding the presence of tax expense change because it can represent the current tax value as well as the deferred tax [12]. ETR indicator can particularly identify behaviors of companies in regards with tax avoidance using temporary difference and permanent difference [6]. Thirdly, ETR value is often used by either decision maker or policymaker as one of instruments in making inference related to corporate taxation system. This is because the indicator can provide the summarized statistics about cumulative impact of tax incentive given in various companies as well as change or fluctuation from corporate tax in detail and easy use [11].

Operational definition and variable measurement used in this study is presented in the Table I.

TABLE I: OPERATIONAL DEFINITION AND VARIABLE MEASUREMENT

\begin{tabular}{|c|c|c|c|c|c|}
\hline No & Research variables & Indicator & Measurement & Scale & Source \\
\hline & Dependent Variable & & & & \\
\hline \multirow{3}{*}{1} & Tax Aggressiveness & \multirow[b]{2}{*}{ ETR } & \multirow[b]{2}{*}{$E T R=\frac{\text { Tax Expense }}{\text { Profit before Tax }}$} & \multirow[b]{2}{*}{ Ratio } & \multirow[b]{2}{*}{$\begin{array}{l}\text { (Lanis \& } \\
\text { Richardson, } \\
\text { 2012) }\end{array}$} \\
\hline & $\begin{array}{l}\text { Measured using ETR that describes total } \\
\text { percentage of tax expense paid by company } \\
\text { divided by total profit before tax earned by } \\
\text { company. }\end{array}$ & & & & \\
\hline & Independent Variables & & & & \\
\hline \multirow{5}{*}{2} & Political Connection & & & & \\
\hline & - Directors (DIR) & \multirow[b]{2}{*}{ DIR } & \multirow{2}{*}{$D I R=\frac{\text { The number of political connection of the DIR }}{\text { Total DIR }}$} & \multirow[b]{2}{*}{ Ratio } & \multirow[b]{2}{*}{$\begin{array}{l}\text { Iswari et al. } \\
\qquad \text { (2019) }\end{array}$} \\
\hline & $\begin{array}{l}\text { Measured from the ratio between the } \\
\text { proportion of political connection of the DIR } \\
\text { and total number of Board of Directors }\end{array}$ & & & & \\
\hline & - Board of Commissioners (BOC) & & & & \\
\hline & $\begin{array}{l}\text { Measured from the ratio between proportion } \\
\text { of political connection of COM and total } \\
\text { number of Board of Commissioners }\end{array}$ & BOC & $B O C=\frac{\text { The number of political connection of the BOC }}{\text { Total BOC }}$ & Ratio & $\begin{array}{l}\text { Iswari et al. } \\
\qquad \text { (2019) }\end{array}$ \\
\hline \multirow[b]{2}{*}{3} & Institutional Ownership (IO) & \multirow[b]{2}{*}{$\mathrm{IO}$} & \multirow[b]{2}{*}{$I O=\frac{\text { Total number of stocks owned by institution }}{\text { Total number of stocks available }}$} & \multirow[b]{2}{*}{ Ratio } & \multirow[b]{2}{*}{$\begin{array}{l}\text { Ying } \\
(2017)\end{array}$} \\
\hline & $\begin{array}{l}\text { Measured from the ratio between the total } \\
\text { number of stocks owned by institution and } \\
\text { total number of stocks available }\end{array}$ & & & & \\
\hline & Control Variables & & & & \\
\hline \multirow[b]{2}{*}{4} & Profitability & \multirow[b]{2}{*}{ ROA } & \multirow[b]{2}{*}{$R O A=\frac{\mathrm{EAT}}{\text { Total Assets }}$} & \multirow[b]{2}{*}{ Ratio } & \multirow[b]{2}{*}{$\begin{array}{l}\text { Kim \& } \\
\text { Zhang } \\
(2016)\end{array}$} \\
\hline & $\begin{array}{l}\text { Ratio that measures corporate ability in } \\
\text { earning profit available to stockholders } \\
\text { through total assets }\end{array}$ & & & & \\
\hline \multirow[b]{2}{*}{5} & Leverage & \multirow[b]{2}{*}{ DAR } & \multirow[b]{2}{*}{$D A R=\frac{\text { Total Liability }}{\text { Total Assets }}$} & \multirow[b]{2}{*}{ Ratio } & \multirow[b]{2}{*}{$\begin{array}{l}\text { Kim \& } \\
\text { Zhang } \\
(2016)\end{array}$} \\
\hline & $\begin{array}{l}\text { Financial ratio that describes relative } \\
\text { proportion between assets and debt used to } \\
\text { fund corporate assets }\end{array}$ & & & & \\
\hline \multirow[b]{2}{*}{6} & Firm Size & \multirow[b]{2}{*}{ SIZE } & \multirow{2}{*}{ SIZE $=$ Ln (Total Assets $)$} & \multirow[b]{2}{*}{ Ratio } & \multirow{2}{*}{$\begin{array}{l}\text { Sudaryono } \\
\text { et al. } \\
(2019)\end{array}$} \\
\hline & $\begin{array}{l}\text { Calculated using Natural Logarithm from the } \\
\text { total assets of each company }\end{array}$ & & & & \\
\hline \multirow[b]{2}{*}{7} & Capital Intensity & \multirow[b]{2}{*}{ CINT } & \multirow[b]{2}{*}{$C I N T=\frac{\text { Total Fixed Assets }}{\text { Total Assets }}$} & \multirow[b]{2}{*}{ Ratio } & \multirow[b]{2}{*}{$\begin{array}{l}\text { Lanis \& } \\
\text { Richardson } \\
\text { (2012) }\end{array}$} \\
\hline & $\begin{array}{l}\text { Measured from the ratio between total fixed } \\
\text { assets and total assets in the company }\end{array}$ & & & & \\
\hline & Inventory Intensity & & & & \\
\hline 8 & $\begin{array}{l}\text { Measured from the ratio between total } \\
\text { inventory and total assets in the company }\end{array}$ & INVINT & $I N V I N T=\frac{\text { Total Inventory }}{\text { Total Assets }}$ & Ratio & $\begin{array}{l}\text { Lanis \& } \\
\text { Richardson } \\
\text { (2012) }\end{array}$ \\
\hline
\end{tabular}

\section{Data Analysis Techniques and Hypothesis Test}

This study uses panel regression analysis to test the hypothesis. Before performing the regression analysis, model specification test was conducted using chow test, Hausman test, and Langrange multiplier test. Then classical assumption test was performed to assure regression model was free from classical assumption problem. The following is regression equation used in this study.

$$
\begin{aligned}
& \mathrm{ETR}=\alpha+\beta_{1} \mathrm{DIR}_{\text {it }}+\beta_{2} \mathrm{BOC}_{\text {it }}+\beta_{3} \mathrm{IO}_{\text {it }}+\beta_{4} \mathrm{ROA}_{\text {it }}+\beta_{5} \mathrm{DAR}_{\mathrm{it}} \\
& +\beta_{6} \mathrm{LnSIZE}_{\mathrm{it}}+\beta_{7} \mathrm{CINT}_{\mathrm{it}}+\beta_{8} \mathrm{INVINT}_{\mathrm{it}}+\mathrm{e} \ldots
\end{aligned}
$$

A: Constant

$b_{1}-b_{8}$ : Regression coefficient from each variable

DIR: Director's political connection

BOC: Political Connection of Board of Commissioners

IO: Institutional Ownership;

ROA: Return on assets;

DAR: Debt to assets ratio;

SIZE: Natural Logarithm of total assets;

CINT: Capital intensity;

INVINT: Inventory intensity;

E: Error Term.

where

ETR: Effective tax rate 


\section{RESUlt AND Discussion}

\section{A. Descriptive Statistics}

Result of descriptive statistical analysis on Table II shows ETR dependent variable has 0.43 as its highest score and 0.16 as its lowest score, while the mean value is 0.26 and its standard deviation is 0.05 . The variable data distribution can be considered normal because the value of its standard deviation is lower than the mean value.

TABLE II: RESULT OF DESCRIPTIVE STATISTICS

\begin{tabular}{|c|c|c|c|c|c|c|c|c|c|}
\hline & $E T R$ & DIR & BOC & IO & ROA & $D A R$ & SIZE & CINT & INVINT \\
\hline Mean & 0.263422 & 0.214098 & 0.395384 & 0.676977 & 0.072448 & 0.426321 & 14.59675 & 0.373868 & 0.197301 \\
\hline Median & 0.252856 & 0.200000 & 0.333333 & 0.723338 & 0.054899 & 0.424794 & 14.41035 & 0.331394 & 0.188660 \\
\hline $\operatorname{Max}$ & 0.434084 & 0.500000 & 0.750000 & 0.992127 & 0.371130 & 0.844597 & 18.38545 & 0.806130 & 0.574974 \\
\hline Min & 0.160754 & 0.000000 & 0.200000 & 0.000000 & -0.176123 & 0.032674 & 11.98020 & 0.049577 & 0.001550 \\
\hline Std. Dev. & 0.052165 & 0.128420 & 0.093209 & 0.236314 & 0.075419 & 0.184964 & 1.307170 & 0.175416 & 0.106145 \\
\hline Observ. & 310 & 310 & 310 & 310 & 310 & 310 & 310 & 310 & 310 \\
\hline
\end{tabular}

Source: Result of data processing.

The independent variable director's political connection (DIR) has mean value 0.21 with its highest score 0.50 and lowest score 0.00 . Variable political connection of board of commissioners (BOC) has highest score 0.75 and lowest score 0.20 with mean value 0.39 . According to the data description, it can be concluded that the political connection of board of commissioners is higher than the board of directors. Variable institutional ownership (IO) has mean value 0.67 with its higher score 0.99 and lowest score 0.00 . The result indicates that most of the company samples studied have relatively high institutional ownership.

\section{B. Regression Analysis}

According to Chow test, Hausman test, and Lagrange Multiplier test, the appropriate model to be used is fixed effects. Furthermore. Results of normality test, heteroscedasticity test, multicollinearity test, and autocorrelation test show that regression model is free from classical assumption problem. Results of panel regression analysis are presented in the following Table III.

\begin{tabular}{llll}
\multicolumn{4}{c}{ TABLE III: REGRESSION ANALYSIS RESULT } \\
\cline { 2 - 4 } Variable & Coeff. & $\boldsymbol{t}$-statistic & p-value \\
\hline $\boldsymbol{C}$ & 0.407 & 1.653 & 0.100 \\
DIR & -0.146 & -2.696 & 0.008 \\
BOC & -0.033 & -0.671 & 0.503 \\
IO & -0.371 & -1.769 & 0.078 \\
ROA & -0.014 & -0.165 & 0.869 \\
DAR & 0.043 & 1.354 & 0.177 \\
SIZE & 0.006 & 0.498 & 0.619 \\
CINT & 0.089 & 2.438 & 0.016 \\
INVINT & 0.065 & 0.866 & 0.387 \\
$\boldsymbol{R}^{2}$ & 0.636 & & \\
Adj $\boldsymbol{R}^{2}$ & 0.532 & & \\
$\boldsymbol{F}$-value & 6.084 & & \\
Sig. & 0.000 & & \\
$\boldsymbol{N}$ & 310 & & \\
\hline
\end{tabular}

Result from the data analysis shows regression coefficient value of the director's political connection variable is -0.146 with p-value 0.008 . That means the director's political connection has negative effect and is significant toward ETR. This can be interpreted as the stronger the political connection of the board of directors, the higher the level of tax aggressiveness committed by the company. Therefore, the first hypothesis in this study is accepted. This result is consistent with the study by reference [16] and indicates the role of political connection among the board of directors is quite significant toward tax aggressiveness. Directors with political connection tend to be more aggressive in taking advantage of the loopholes in tax regulation because they feel they will have protection against the risks while being detected by the revenue officers.

The next analysis result shows the coefficient value of political connection of board of commissioners' variable is 0.033 with p-value 0.503 . This means the political connection of the board of commissioners does not have significant effect toward ETR. According to the analysis, the second hypothesis in this study is rejected hence. This result supports the study by reference [13]. Although the mean value of the board of commissioners is higher than the mean value of the board of directors, the board of commissioners as the representative of the company owner seems to be still more careful in the practice of taxation.

Furthermore, analysis result on table III shows regression coefficient value of institutional ownership variable is -0.371 with $\mathrm{p}$-value 0.078 . This result means that institutional ownership has negative effect and is significant toward ETR on significant level $10 \%$. Although the effect is significant, the vector of the regression coefficient directs to the opposite side of the hypothesis. Therefore, the third hypothesis in this study is rejected. This result indicates that mechanism of the corporate management is yet to be effective. The role of institutional ownership to monitor the implementation of corporate governance within a company most likely is not effective. Nonetheless, there is a probability that the orientation of the institutional owner is only for short-term benefit. This suggests that the investment by the institutional owners is only for a short amount of time, hence their orientation is not to maintain the reputation of the company in a long run but only to earn profit out of short-term investment [15]. The analysis result for the control variables toward tax aggressiveness shows that only capital intensity that has significant effect.

\section{Additional Analysis}

Additional analysis was performed by redoing the regression for the research model using another measurement on tax aggressiveness variable, i.e. book tax differences (BTD). This is to find out if this study is consistent. Moreover, the samples are also divided into two groups, big companies and small companies. Result of additional analysis is presented on Table IV and V. 
TABLEIV: ANALYSIS RESULT ON VARIABLE MEASUREMENT COMPARING BETWEEN ETR AND BTD

\begin{tabular}{|c|c|c|c|c|c|c|}
\hline \multirow[b]{2}{*}{ Variable } & \multicolumn{3}{|c|}{ ETR } & \multicolumn{3}{|c|}{ BTD } \\
\hline & Coeff. & $\begin{array}{c}t- \\
\text { statistic }\end{array}$ & $\begin{array}{c}p- \\
\text { value }\end{array}$ & Coeff. & $\begin{array}{c}t- \\
\text { statistic }\end{array}$ & $\begin{array}{c}p- \\
\text { value }\end{array}$ \\
\hline$C$ & 0.407 & 1.653 & 0.100 & -0.008 & -0.164 & 0.870 \\
\hline DIR & -0.146 & -2.696 & 0.008 & -0.023 & -1.691 & 0.092 \\
\hline BOC & -0.033 & -0.671 & 0.503 & -0.026 & -2.568 & 0.011 \\
\hline IO & -0.371 & -1.769 & 0.078 & -0.034 & -0.830 & 0.408 \\
\hline $\boldsymbol{R O A}$ & -0.014 & -0.165 & 0.869 & -0.184 & -10.810 & 0.000 \\
\hline$D A R$ & 0.043 & 1.354 & 0.177 & -0.001 & -0.097 & 0.922 \\
\hline$S I Z E$ & 0.006 & 0.498 & 0.619 & 0.002 & 0.916 & 0.361 \\
\hline CINT & 0.089 & 2.438 & 0.016 & 0.012 & 1.737 & 0.084 \\
\hline$I N V I N T$ & 0.065 & 0.866 & 0.387 & 0.004 & 0.287 & 0.775 \\
\hline$R^{2}$ & 0.636 & & & 0.929 & & \\
\hline $\operatorname{Adj} R^{2}$ & 0.532 & & & 0.908 & & \\
\hline F-value & 6.084 & & & 45.363 & & \\
\hline Sig. & 0.000 & & & 0.000 & & \\
\hline$N$ & 310 & & & 310 & & \\
\hline
\end{tabular}

Source: Result of data processing.

TABLE V: ANALYSIS RESULT OF COMPARISON BETWEEN BIG COMPANIES AND SMALL COMPANIES

\begin{tabular}{lcccccc}
\hline \multirow{2}{*}{ Variable } & \multicolumn{3}{c}{ Small Companies } & \multicolumn{3}{c}{ Big Companies } \\
\cline { 2 - 7 } & Coeff. & $\begin{array}{c}\boldsymbol{t} \text { - } \\
\text { statistic }\end{array}$ & $\begin{array}{c}\boldsymbol{p} \text { - } \\
\text { value }\end{array}$ & Coeff. & $\begin{array}{c}\boldsymbol{t} \text { - } \\
\text { statistic }\end{array}$ & $\begin{array}{c}\boldsymbol{p} \text { - } \\
\text { value }\end{array}$ \\
\hline $\boldsymbol{C}$ & 0.321 & 0.027 & 0.978 & 0.369 & 1.448 & 0.150 \\
DIR & -0.206 & -2.101 & 0.038 & -0.079 & -1.098 & 0.275 \\
BOC & -0.077 & -1.090 & 0.278 & 0.035 & 0.502 & 0.617 \\
$\boldsymbol{I O}$ & 0.079 & 0.005 & 0.996 & -0.384 & -1.775 & 0.079 \\
$\boldsymbol{R O A}$ & -0.053 & -0.429 & 0.669 & -0.003 & -0.021 & 0.983 \\
$\boldsymbol{D A R}$ & 0.004 & 0.064 & 0.949 & 0.046 & 1.114 & 0.268 \\
SIZE & -0.003 & -0.152 & 0.879 & 0.006 & 0.451 & 0.653 \\
$\boldsymbol{C I N T}$ & 0.018 & 0.246 & 0.806 & 0.128 & 2.891 & 0.005 \\
$\boldsymbol{I N V I N T}$ & 0.072 & 0.711 & 0.478 & -0.117 & -0.919 & 0.360 \\
$\boldsymbol{R}^{2}$ & 0.691 & & & 0.578 & & \\
Adj $\boldsymbol{R}^{2}$ & 0.590 & & & 0.439 & & \\
$\boldsymbol{F}$-value & 6.835 & & & 4.175 & & \\
Sig. & 0.000 & & & 0.000 & & \\
$\boldsymbol{N}$ & 155 & & & 155 & & \\
\hline
\end{tabular}

Source: Result of data processing

According to the regression analysis using BTD, the result is rather inconsistent in terms of significance in the relation between variables. While using ETR to determine analyze the significance of political connection of the board of commissioners toward tax aggressiveness, the result is not significant. However, analysis using BTD shows the opposite, the political connection of the board of commissioners has significant effect toward tax aggressiveness. This inconsistency may be caused by the discrepancy between the groups of companies. In Indonesia Stock Exchange, manufacturing industry group consists of several sectors, e.g. basic industrial sector and chemical sector, as well as consumer goods industry. Government's policy toward each sector of those industries can be different, especially in term of taxation. This can cause discrepancy of ETR and BTD values on each industrial sector. This evidence is supported by the studies [23] and [12] that indicate the discrepancy between ETR and BTD values on each industrial sector caused by different policies applied by government on each sector.

Another additional analysis is comparing the effect of independent variable toward the dependent variable between big and small companies.

Analysis result on table $\mathrm{V}$ shows there is a different effect of director's political connection toward tax aggressiveness between small and big companies. On small companies, the director's political connection has negative effect and is significant toward ETR. However, on big companies the director's political connection is not significant toward ETR despite also having negative effect. This suggests the practice of tax aggressiveness caused by director's political connection is stronger in small companies than big companies. It indicates the size of the company is one of the factors that will determine the corporate management's consideration in committing the practice of tax aggressiveness. In big companies, corporate management tends to comply more with tax regulation. This suggests the presence of bureaucratic incentive effect that explains how the effect of political connection will impact negatively toward tax aggressiveness [30]. The finding also supports the result of a study by [26]. Furthermore, the analysis result on the comparison between the variable political connection of board of commissioners and institutional ownership toward tax aggressiveness on big and small companies shows relatively insignificant effect, although the vectors of regression coefficient between the big and small companies are on the opposite directions.

\section{CONCLUSION}

This study aims to provide empirical evidence regarding the effect of political connection of the directors and board of commissioners as well as the institutional ownership toward tax aggressiveness on manufacturing companies within the period of 2014-2018. The analysis result shows that the political connection of directors and institutional ownership has positive effect and is significant toward tax aggressiveness, while the political connection of the board of commissioners affects positively but insignificantly toward tax aggressiveness. This study indicates the political favoritism effect, and the result supports the study by [30].

Nevertheless, the additional analysis result using the Book Tax Differences as another instrument to measure tax aggressiveness shows relatively consistent result compared to the previous one (using ETR), especially the political connection of the directors toward tax aggressiveness. Analysis result on big and small companies shows that the effect of director's political connection is more significant on small companies than big companies. This indicates the presence of bureaucratic incentive effect on big companies.

\section{LIMITATION AND SUGGESTION}

This study is limited in some aspects and has some suggestions for more studies in the future. First of all, this study only analyzes the political connection quantitatively, and is yet to consider the qualitative aspect as well as the 
level of the political connection owned by the directors and board of commissioners. Although the directors and the board of commissioners have connection with the executive, legislative, and judicative bodies, how much the political connection they have can affect the policies in those governmental bodies is yet to be taken into account in this study. Therefore, future studies are expected to be able to analyze those factors. For instance, a scenario in which the directors and members of the board of commissioners also hold political position can be studied further.

The second limitation in this study is concerning the data of political connection for both the directors and the board of commissioners. This study only uses the information provided in the profile or biography of the directors and board of commissioners in the annual financial report and company website to identify the political connection of the directors and board of commissioners. It is possible the track record of the directors and board of commissioners in governmental bodies or political parties is not fully transparently provided from those two sources. Therefore, future studies are suggested to explore more the information regarding the political connection of the directors and board of commissioners from other data sources, e.g. on website of political parties and website of respective ministries and state agencies.

\section{REFERENCES}

[1] Adhikari, A., Derashid, C., \& Zhang, H. (2006). Public policy, political connections, and effective tax rates: Longitudinal evidence from Malaysia. Journal of Accounting and Public Policy, 25(5), 574-595. https://doi.org/10.1016/j.jaccpubpol.2006.07.001.

[2] Armstrong, C. S., Blouin, J. L., \& Larcker, D. F. (2012). The incentives for tax planning. Journal of Accounting and Economics, 53(1-2), 391411. https://doi.org/10.1016/j.jacceco.2011.04.001.

[3] Balakrishnan, K., Blouin, J. L., \& Guay, W. R. (2017). Tax aggressiveness and corporate transparency. Accounting Review, 94(1), 45-69. https://doi.org/10.2308/accr-52130.

[4] Brown, J., Drake, K., \& Wellman, L. (2014). The benefits of a relational approach to corporate political activity: Evidence from political contributions to tax policymakers. The Journal of the American Taxation Association, 37(1), 69-102.

[5] Bushee, B. J. (2001). Do Institutional Investors Prefer Near-Term Earnings over Long-Run Value?. Contemporary Accounting Research, 18(2), 207-246. https://doi.org/10.1506/J4GU-BHWH-8HME-LE0X.

[6] Chen, S., Chen, X., Cheng, Q., \& Shevlin, T. (2010). Are family firms more tax aggressive than non-family firms?. Research Collection School of Accountancy, 91(1), 41-61.

[7] Chen, X. (2018). Corporate Social Responsibility Disclosure, Political Connection and Tax Aggressiveness: Evidence from China's Capital Markets. Journal of Business and Management, 6(1), 151-164. https://doi.org/10.4236/ojbm.2018.61010.

[8] CNN Indonesia. (2016). Panama Papers dan Praktik Penghindaran Pajak. From www.cnnindonesia.com. Website: https://www.cnnindonesia.com/ekonomi/20160412112445-79123307/panama-papers-dan-praktik-penghindaran-pajak.

[9] Dyreng, S. D., Hanlon, M., \& Maydew, E. L. (2008). Long-run corporate tax avoidance. Accounting Review, 83(1), 61-82. https://doi.org/10.2308/accr.2008.83.1.61.

[10] Goldman, E., Rocholl, J., \& So, J. (2009). Do politically connected boards affect firm value. Review of Financial Studies, 22(6), 23312360. https://doi.org/10.1093/rfs/hhn088.

[11] Gupta, S., \& Newberry, K. (1997). Determinants of the variability in corporate effective tax rates: Evidence from longitudinal data. Journal of Accounting and Public Policy, 16(1), 1-34. https://doi.org/10.1016/S0278-4254(96)00055-5.

[12] Hanlon, M., \& Heitzman, S. (2010). A review of tax research. Journal of Accounting and Economics, 50(2-3), 127-178. https://doi.org/10.1016/j.jacceco.2010.09.002.

[13] Iswari, P., Sudaryono, E. A., \& Widarjo, W. (2019). Political connection and tax aggressiveness: A study on the state-owned enterprises registered in Indonesia stock exchange. Journal of International Studies, 12(1), 79-92. https://doi.org/10.14254/2071$8330.2019 / 12-1 / 5$.

[14] Kemenkeu.go.id. (2019). Target dan Realisasi Penerimaan Pajak Tahun 2010 - 2020. From www.kemenkeu.go.id. Website: https://kemenkeu.go.id/target-dan-realisasi-penerimaan-pajak-tahun2010-2020/.

[15] Khurana, I. K., \& Moser, W. J. (2009). Institutional Ownership and Tax Aggressiveness. SSRN Electronic Journal, $0-42$. https://doi.org/10.2139/ssrn.1464106.

[16] Kim, C., \& Zhang, L. (2016). Corporate Political Connections and Tax Aggressiveness. Contemporary Accounting Research, 33(1), 115120. https://doi.org/10.1111/1911-3846.12214.

[17] Kubick, T. R., \& Lockhart, G. B. (2017). Corporate tax aggressiveness and the maturity structure of debt. Advances in Accounting, 36, 5057. https://doi.org/10.1016/j.adiac.2016.10.001.

[18] Lanis, R., \& Richardson, G. (2012). Corporate social responsibility and tax aggressiveness: An empirical analysis. Journal of Accounting and Public Policy, 31(1), 86-108. https://doi.org/10.1016/j.jaccpubpol.2011.10.006.

[19] Leuz, C., \& Oberholzer-Gee, F. (2006). Political relationships, global financing, and corporate transparency: Evidence from Indonesia. Journal of Financial Economics, 81(2), 411-439. https://doi.org/10.1016/j.jfineco.2005.06.006.

[20] Li, C., Wang, Y., Wu, L., \& Xiao, J. Z. (2016). Political connections and tax-induced earnings management: evidence from China. European Journal of Finance, 22(4-6), 413-431 https://doi.org/10.1080/1351847X.2012.753465.

[21] Milyo, J., Primo, D., \& Groseclose, T. (2000). Corporate PAC Campaign Contributions in Perspective. Business and Politics, 2(1), 75-88. https://doi.org/10.2202/1469-3569.1004.

[22] Moore, J. A. (2012). Empirical evidence on the impact of external monitoring on book-tax differences. Advances in Accounting, 28(2), 254-269. https://doi.org/10.1016/j.adiac.2012.06.002.

[23] Plesko, G. A. (2002). Reconciling Corporation Book and Tax Net Income, Tax Years 1996-1998. SOI Bulletin, 21(4), 1-16.

[24] Pranoto, B. A., \& Widagdo, A. K. (2016). Pengaruh Koneksi Politik Dan Corporate Governance Terhadap Tax Agressiveness. Syariah Paper Accounting FEB UMS, 1(3), 472-486.

[25] Shleifer, A., \& Vishny, R. W. (2002). The Grabbing Hand: Government Pathologies and Their Cures. Harvard University Press.

[26] Sudaryono, E. A., Rahmawati, Djuminah, Wartono, \& Widarjo, W. (2019). Relationship of political connection and tax aggressiveness: Empirical evidence from Indonesia. International Journal of Economic Policy in Emerging Economies, 12(5), 453-465.

[27] Wahab, E. A. A., Ariff, A. M., Marzuki, M. M., \& Sanusi, Z. M. (2017). Political connections, corporate governance, and tax aggressiveness in Malaysia. Asian Review of Accounting, 25(3), 424451. https://doi.org/10.1108/ARA-05-2016-0053.

[28] Wei, Z., Xie, F., \& Zhang, S. (2005). Ownership Structure and Firm Value in China's Privatized Firms: 1991-2001. Journal of Financial and Quantitative Analysis (JFQA), 40(1), 87-108.

[29] Ying, T., Wright, B., \& Huang, W. (2017). Ownership Structure and Tax Aggressiveness of Chinese Listed Companies. International Journal of Accounting \& Information Management, 25(3), 313-332. https://doi.org/10.1108/IJAIM-07-2016-0070.

[30] Zhang, H., Li, W., \& Jian, M. (2012). How does state ownership affect tax avoidance? Evidence from China. Singapore Management University, School of Accountancy, 13-18. 


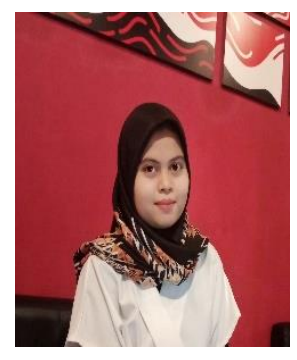

Yety Anggraini was born in Karanganyar, Central Java on May 07, 1995. She received her Bachelor degree in 2017 from STIE AUB Surakarta, majoring in Accounting. She currently pursuing her Master degree at Sebelas Maret University majoring in Master of Accounting study program. Her working experience i.e worked at retail company (PT. Central Motor Sandy Sakti) in Surakarta as accounting staff from August 2017 until September 2019.

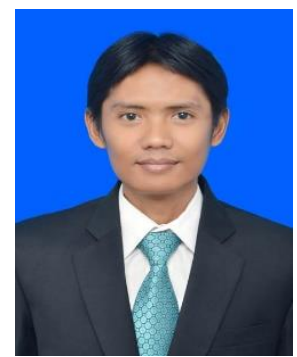

Wahyu Widarjo is a Lecturer in Financial Accounting and Taxation at the Faculty of Economics and Business, Universitas Sebelas Maret, Indonesia. He holds a Doctoral degree from the Universitas Sebelas Maret, Indonesia. $\mathrm{He}$ has published a number of papers in reputed journals including International of Journal of Business and Society, International Journal of Learning and Intellectual Capital, Journal of International Studies and Global Business Review. 